\title{
Lymphangioleiomyomatosis as a rare cause of recurrent pneumothorax in women
}

\author{
Małgorzata Wojtyś ${ }^{1}$, Paweł Rogoziński², Jacek Alchimowicz ${ }^{1}$, Piotr Wandzel ${ }^{3}$, Adam Bubel ${ }^{2}$, \\ Tomasz Grodzki ${ }^{1}$, Krzysztof Bruliński ${ }^{2}$
}

${ }^{1}$ Department of General Thoracic Surgery, Pomeranian Medical University, Szczecin 2Division of Thoracic Surgery, Pulmonology and Thoracic Surgery Center, Bystra

${ }^{3}$ Department of Pathomorphology, Beskidy Oncology Center, Bielsko-Biała

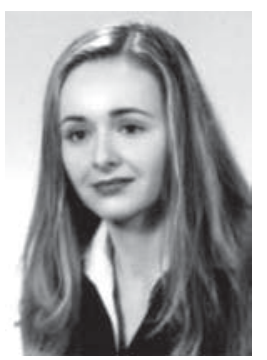

Kardiochirurgia i Torakochirurgia Polska 2013; 10 (2): 161-164

\begin{abstract}
This paper presents five cases of women, aged between 25 and 44, treated surgically for pneumothorax in the course of lymphangioleiomyomatosis (LAM). Initially, they were treated by means of suction drainage of the pleural cavity, which was then followed by surgical procedures (resection of lung tissue with emphysematous bullae, pleurectomy, chemical pleurodesis with talc or doxycycline). All the operations were performed as minimally invasive procedures (VATS). In three women bilateral pneumothorax was observed, in one right-sided recurrent pneumothorax, and in one right-sided recurrent pneumothorax and left-sided pneumothorax were revealed. Tests revealed the presence of renal angiomyolipoma in two women and suspicion of renal angiomyolipoma in one patient. One of the patients was operated on due to uterine fibroids at the age of 36, and was treated for chylothorax. The surgical procedures applied were symptomatic. At present, lung transplantation is an essential method of therapy in the final period of LAM.

Key words: recurrent pneumothorax, lymphangioleiomyomatosis, surgical treatment.
\end{abstract}

\section{Introduction}

Lymphangioleiomyomatosis (LAM) is a rare disease that may occur sporadically (S-LAM) or may be associated with tuberous sclerosis complex (TSC-LAM). In its sporadic form, it is diagnosed with the incidence of 1 per 400,000 adult women, and $30-40 \%$ of adult female patients suffering from TSC are also diagnosed with LAM [1]. LAM is characterized by non-neoplastic proliferation of atypical smooth muscle cells (LAM cells) within the walls of lymph and blood vessels, in chest and abdominal lymph nodes, and in the walls of the bronchi $[2,3]$. The result of pathological smooth muscle cell growth in the lungs is the de-

\section{Streszczenie}

W pracy przedstawiono pięć przypadków kobiet w wieku 25-44 lat leczonych chirurgicznie z powodu odmy opłucnowej w przebiegu limfangioleiomiomatozy (LAM). Początkowo stosowano u opisanych pacjentek drenaż ssący jamy opłucnowej, a w kolejnym etapie leczenie operacyjne (resekcja miąższu płuca wraz z pęcherzami rozedmowymi, pleurektomia, pleurodeza chemiczna talkiem lub doksycykliną). Wszystkie operacje wykonano techniką małoinwazyjną (video-assisted thoracoscopic surgery - VATS). U trzech pacjentek obserwowano odmę opłucnową obustronną, u jednej prawostronną nawrotową, $u$ jednej prawostronną nawrotową oraz lewostronną. $\mathrm{U}$ dwóch chorych stwierdzono angiomiolipomę nerki, a u jednej ją podejrzewano. Jedna z chorych operowana była z powodu mięśniaków macicy w 36. roku życia oraz leczona z powodu chłonkotoku. Stosowane leczenie chirurgiczne miało charakter objawowy. Obecnie istotną metodą leczenia LAM w schyłkowym okresie choroby jest przeszczepienie płuc.

Słowa kluczowe: nawrotowa odma opłucnowa, limfangioleiomiomatoza, leczenie chirurgiczne.

struction of pulmonary alveolar septa and the development of numerous cysts [2]. Development of angiomyolipoma lesions, primarily in the kidneys, can also be observed in approximately $50 \%$ of patients, and uterine fibroids occur in approximately $37 \%$ of patients [4]. Respiratory symptoms are prevalent in the clinical picture of LAM as an interstitial lung disease, and they include dyspnea (59\%), pneumothorax (49\%), and cough (39\%), as well as hemoptysis, chest pains and chylothorax [2, 5-7]. Case studies of 5 patients are presented below; they were all treated for recurrent pneumothorax, but, ultimately, received the confirmed diagnosis of LAM.

Address for correspondence: Małgorzata Wojtyś, Department of General Thoracic Surgery, Pomeranian Medical University, Specialistic Hospital named Prof. A. Sokołowski, 70-891 Szczecin-Zdunowo, Alfreda Sokołowskiego 11, tel. +48 914427272 , fax +48 9146201 34, e-mail: margaretkaw@wp.pl 


\section{Case study 1}

The patient, aged 25 , was urgently admitted to the thoracic surgery department in April 2006, due to bilateral pneumothorax. She complained of decreased exercise tolerance, which had persisted for about a month. When she was 17, the patient underwent the removal of a tumor from her left external acoustic meatus. At 22, she had her left kidney removed (angiomyolipoma), and, in 2005, she again underwent the removal of a tumor from the left external acoustic meatus (syringoma). On the day of her admission, she was in poor general condition and exhibited dyspnea at rest, pain in the vicinity of the scapulas, and signs of bilateral pneumothorax in radiological examination. Both pleural cavities were urgently drained. During the treatment, air leakage from both drains was observed. The patient was qualified for videothoracoscopic left pleurectomy. Resection of the apex of the lung and pleurectomy were performed employing a minimally invasive approach. Histopathological evaluation of the acquired tissue samples revealed the following: 1) the parietal pleura - chronic fibrous pleuritis, and 2) the apex of the left lung - pleural fibrosis and bullous emphysema. The patient was discharged in good general condition. She was admitted again in June 2006 for planned surgery of the other side. Spirometry revealed forced expiratory volume in one second $\left(\mathrm{FEV}_{1}\right) 50 \%$, and forced vital capacity (FVC) ex $47 \%$. Right pleurectomy was performed and a part of segment 6 of the right lung was excised. LAM was diagnosed by histopathological analysis. During a follow-up examination in May 2008, spirometry was performed (FEV $69.2 \%$, FVC 62\%), and a chest CT (computed tomography) scan was performed, which revealed that the whole lungs were dotted with numerous cysts up to $3 \mathrm{~cm}$ in size. In March 2011, the patient underwent surgery due to ectopic pregnancy. Follow-up chest CT performed in June 2011 did not demonstrate any significant difference in comparison to the previous evaluation. The patient remains under observation.

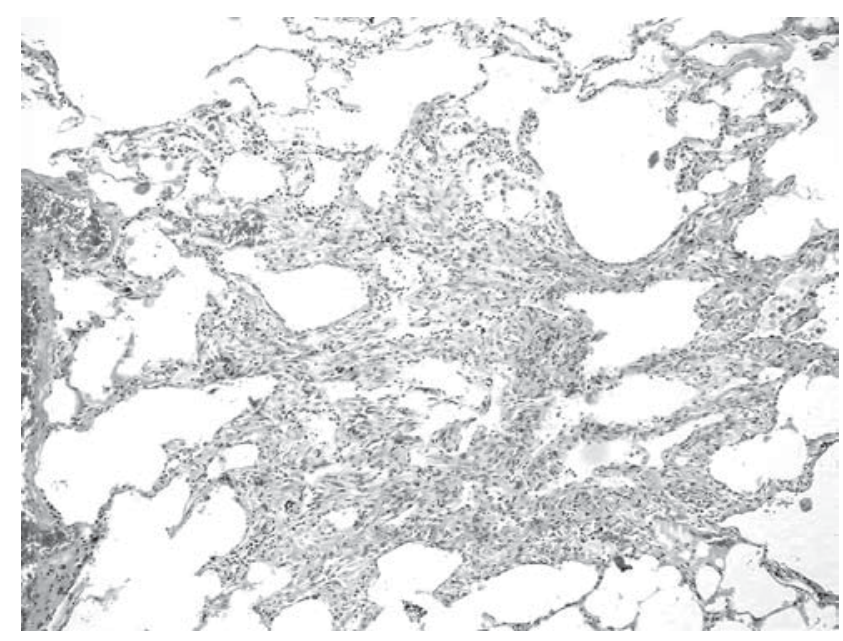

Fig. 1. A lung parenchyma sample with a small focus of spindle cells and epithelioid cells around the fissure-like vessels. HE stain. Magnification 100x

\section{Case study 2}

The patient was aged 33; she had smoked 10 cigarettes daily for 18 years and had been treated 5 years before with drainage of the pleural cavity due to spontaneous right-sided pneumothorax. Her medical history included two caesarean sections. In February 2007, she had been treated for spontaneous bilateral pneumothorax with bilateral drainage. Considering the failure of the previously employed treatment, a wedge resection of the upper and middle lobes was performed, accompanied by pleurectomy using a minimally invasive access. Histopathological examination of tissue samples acquired operatively revealed pulmonary fibrosis and emphysematous bullae. The patient was once more admitted to the thoracic surgery department in February 2009, due to recurrent bilateral pneumothorax. After being admitted, she complained of discomfort on the left side of the chest. A resection of the apex and segment 6 of the left lung was performed, accompanied by pleurectomy. LAM was diagnosed by histopathological analysis. Immunohistochemical examination revealed: desmin (+), smooth muscle actin (SMA) (+), human melanoma black 45 (HMB 45) (+), estrogen receptor (ER) (+), progesterone receptor (PGR) (+). The patient was discharged in good general condition.

\section{Case study 3}

The patient, aged 44, complained of dyspnea and cough persisting for about a month. She had smoked cigarettes in the past. She was referred to the hospital due to suspicion of right lung inflammation in April 2010. Additional examinations revealed: $\mathrm{FEV}_{1} 1.5$ । (57\%), FVC ex 2.0 । (66\%), total lung capacity (TLC) 5.05 l. The patient was transferred to the thoracic surgery department, due to right-sided pneumothorax. She was treated with drainage of the right pleural cavity. Re-expansion of the right lung was achieved, and, after air leakage subsided, the drain was removed. The patient was discharged in good general condition. In June 2011, she experienced sudden sharp pain and dyspnea at rest, which increased during exercise. The presence of recurrent right-sided pneumothorax was determined radiologically. Subsequently, wedge resection of the apex of the right lung was performed, accompanied by VATS pleurodesis. LAM was diagnosed by histopathological analysis (Fig. 1). Immunohistochemical revealed: actin (+), SMA (+), HMB-45 (+) (Fig. 2). In August 2011, the patient's right-sided pneumothorax recurred. She was treated with drainage of the right pleural cavity and talc pleurodesis. Air leakage subsided after twelve days. In February 2012, the patient was admitted to the pulmonary diseases ward in order to assess the dynamics of the disease and perform control examinations. The evaluation yielded the following results: diffusing capacity of the lung for carbon monoxide (DLCO) 84\%, TLC 135\%. The patient did not report any complaints. Abdominal CT scan results indicated angiomyolipoma of the right kidney. The patient was once more treated with drainage of the pleural cavity in April 2012, due to recurrent right-sided pneumothorax 


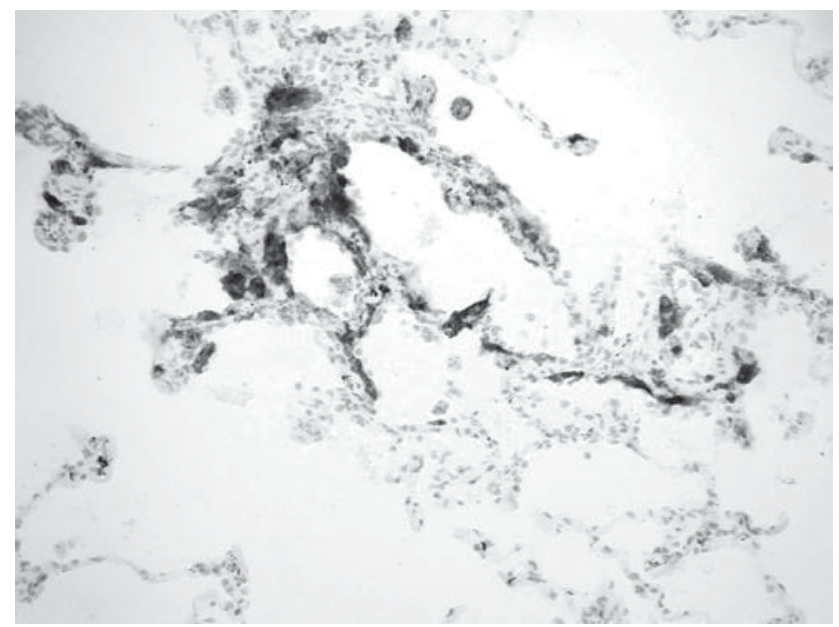

Fig. 2. The HMB-45 test result, which demonstrated the presence of lymphangioleiomyomatosis cells. Magnification 200x

(Fig. 3). Due to a prolonged air leak, chemical pleurodesis was performed. The applied treatment turned out to be efficacious; the patient was discharged home and remains under follow-up observation.

\section{Case study 4}

The patient, aged 29, an occasional smoker, was admitted to the thoracic surgery department in June 2011, due to spontaneous right-sided pneumothorax. After admission, she complained of strong stitching pains in the right side of the chest, accompanied by a feeling of dyspnea. The patient was treated with drainage of the right pleural cavity. Re-expansion of the lung was confirmed by radiological evaluation, after which the patient was discharged in good general condition. The patient was treated in the thoracic surgery department again in October 2011, due to left-sided pneumothorax. After admission, she complained of leftsided chest pain. Drainage of the left pleural cavity was performed, followed by resection of the apex of the left lung and the present emphysematous bullae; subsequently, VATS pleurectomy was performed. Microscopic evaluation of the acquired operative samples indicated LAM.

The sample results were consulted with R. Langfort, M.D. from the Pathomorphology Department of the Institute of Tuberculosis and Lung Diseases in Warsaw. Immunohistochemical revealed: actin (+), HMB-45 (+), melan-A (-). The patient was once more admitted to the thoracic surgery department in March 2012, due to recurrence of rightsided pneumothorax. After admission, she complained of dyspnea at rest and chest pain. Drainage of the right pleural cavity was performed, followed by resection of the apex of the right lung and the present emphysematous bullae; subsequently, VATS pleurectomy with pleurodesis was performed. Histopathological evaluation of the removed fragment of lung parenchyma yielded results consistent with the initial diagnosis of LAM. Immunohistochemical evaluation revealed: HMB-45 (+), melan-A (-), actin (+). At the end of March 2012, the patient was again referred to the tho-

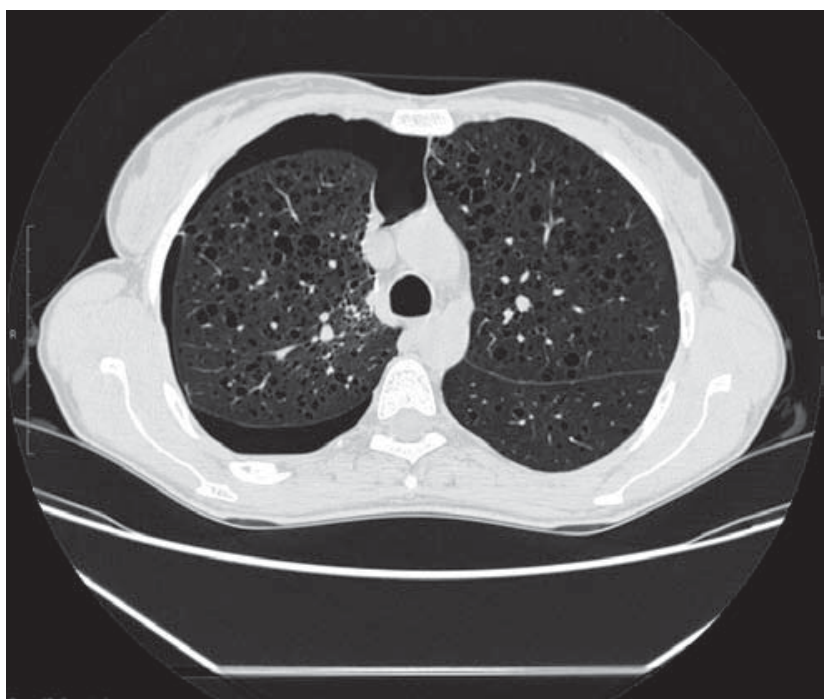

Fig. 3. A HRCT (high resolution computed tomography) image of the patient's chest with visible right-sided pneumothorax occurring in lymphangioleiomyomatosis progression. Lung parenchyma in both lungs exhibits lesions characteristic of lymphangioleiomyomatosis: numerous cystic lesions with thin walls and symmetrical interlobular septa thickening

racic surgery department due to right-sided pneumothorax. The patient was successfully treated with drainage of the right pleural cavity. The patient was discharged in good general condition.

\section{Case study 5}

The patient, aged 40, complaining of dyspnea, was admitted to the thoracic surgery department at the end of June 2012, due to the presence of fluid in the left pleural cavity. Her medical history included partial excision of the superior lobe together with emphysematous bullae, accompanied by talc pleurodesis, in March 2011, due to recurrent left-sided pneumothorax. At this time, the patient received the diagnosis of LAM, based on the histopathological analysis of the acquired samples. Immunohistochemical evaluation revealed: SMA (+), CD 31 (-). Moreover, the patient had had a C-section, and in 2008 she had undergone the removal of uterine fibroids with bilateral wedge resection of the ovaries. She was under observation due to renal angiomyolipoma. On the day of her admission, the patient underwent drainage of the left pleural cavity - $1000 \mathrm{ml}$ of yellow cloudy substance. Control radiological examination performed after the removal of the drain from the left pleural cavity revealed the presence of pneumothorax with fluid accumulating in the right pleural cavity. A drain was inserted into the right pleural cavity, which allowed for the aspiration of $400 \mathrm{ml}$ of lymph and air. The patient was put on a no-fat diet and underwent pleurodesis with doxycycline. Additionally, hormonal treatment with medroxyprogesterone was applied. After the removal of the drain from the right pleural cavity, the patient was discharged home at the beginning of August 2012. 


\section{Discussion}

Although the symptoms of the rare LAM disease may occur in women from puberty to old age, they are usually observed around the age of 33 [3]. The LAM patients presented in this study were 25 to 44 years old. These ages are consistent with reports by other authors [7-9]. Occurrence of the disease in postmenopausal age is rare, and is usually associated with hormone replacement therapy [3]. The symptoms often exhibited by LAM patients include dyspnea, cough, and chest pains [2, 5, 7]. These are accompanied by pneumothorax, as observed in the presented case studies. The differential diagnosis of LAM encompasses numerous disease entities, e.g. primary spontaneous pneumothorax, Langerhans cell histiocytosis, pulmonary emphysema, and other, less frequent conditions [10]. The clinical and radiological picture of these diseases may be similar [5, 6]; thus, the diagnosis of LAM is often delayed to even several years after the presentation of the first symptoms [8]. The LAM is diagnosed based on the presence of lesions in pulmonary parenchyma determined by high-resolution computed tomography (HRCT), and then confirmed histopathologically (by microscopic and immunohistochemical analysis of lung biopsy samples). According to the latest ERS guidelines, it is possible to diagnose LAM definitively without lung biopsy in some patients.

This pertains to persons with the characteristic HRCT picture of the lungs and angiomyolipoma or chylothorax. The primary significance of respiratory function examination parameters, such as $\mathrm{FEV}_{1}$ or DLCO, is their usefulness in determining the severity and progression of the disease [1]. Pneumothorax in LAM is recurrent in nature. Each of the presented patients suffered from at least one recurrence of pneumothorax. The risk of pneumothorax recurrence in LAM is approximately $75 \%$ [1]. Bilateral pneumothorax was observed in 3 out of the 5 described patients; the period after the appearance of their first respiratory symptoms to their LAM diagnosis lasted from 2 months to as long as 7 years. The literature also reports cases in which LAM was diagnosed after as long as several years after the appearance of its first symptoms $[7,8]$. Renal angiomyolipoma was confirmed in two of the studied patients, and suspected in the third. These lesions are frequently revealed in LAM patients $[3,9]$. One of the patients suffered from lymph leaking into the pleural cavity; she was treated with drainage, a no-fat diet, and medroxyprogesterone. Chylothorax is observed in $15-39 \%$ of LAM cases [9]. Spontaneous pneumothorax may be the first symptom of LAM [8]. The ERS guidelines do not recommend performing HRCT for women in whom spontaneous pneumothorax occurs for the first time [1]. According to our own observations, even the first occurrence of spontaneous pneumothorax in women in reproductive age may be related to LAM. Therefore, the performance of HRCT in female patients with firsttime spontaneous pneumothorax would enable the exclusion of the symptomatic nature of the pneumothorax and could help avoid delays in arriving at the proper diagnosis.

\section{References}

1. Johnson S R, Cordier J F, Lazor R, Cottin V, Costabel U, Harari S, ReynaudGaubert M, Boehler A, Brauner M, Popper H, Bonetti F, Kingswood C and the Review Panel of the ERS LAM Task Force. European Respiratory Society guidelines for the diagnosis and management of lympangioleiomyomatosis. Eur Respir I 2010; 35: 14-26.

2. Mastalerz L, Kania A, Papla B, Grzanka P, Niżankowska-Mogilnicka E. Limfangioleiomiomatoza jako jedna z bardzo rzadkich przyczyn chorób śródmiąższowych płuc. Pol Arch Med Wewn 2001; 2: 157-162.

3. Przybylski G, Zielińska J, Nowakowska E, Siemiątkowska K, Pilecki S. Limfangioleiomiomatoza $u$ kobiety w menopauzie stosującej hormonoterapię zastępczą. Pneumonol Alergol Pol 2004; 72: 117-119.

4. Kania A, Mastalerz L, Mogilnicka-Niżankowska E. Limfangioleiomiomatoza. Pol Arch Med Wewn 2001; 3: 249-255.

5. Cohen MM, Pollock-BarZiv S, Johnson SR. Emerging clinical picture of lymphangioleiomyomatosis. Thorax 2005; 60: 875-879.

6. Nasir K, Ahmad A. Giant renal angiomyolipomas and pulmonary lymphangiomyomatosis. Saudi J Kidney Dis Transpl 2010; 21: 314-319.

7. Ye L, Jin M, Bai C. Clinical analysis of patients with pulmonary lymphangioleiomyomatosis (PLAM) in mainland China. Respir Med 2010; 104: 1521-1526.

8. Korzeniewska-Koseła M, Maziarka D, Wesołowski S, Langfort R, Słodkowska J, Bestry I, Kowalski J, Kuś J. Limfangioleiomiomatoza płuc: obraz kliniczny i wyniki leczenia. Pneumonol Alergol Pol 2001; 69: 626-634.

9. Jarzemska A, Lasek W, Nawrot M, Przybylski G, Purzycka-Jazdon A, Kobierowski M. Limphangioleiomiomatosis (LAM): diagnostic problems. Pol J Radiol 2006; 71: 74-77.

10. Harari S, Torre O, Moss J. Lymphangioleiomyomatosis: what do we know and what are we looking for? Eur Respir Rev 2011; 20: 34-44. 